of such courses is now 1,558 , including forty women students : 129 students gained the Diploma during the year. The Council has set up a Panel, under Sir Walter C. Puckey as chairman, to advise them on industrial training for the Diploma in Technology and the collective responsibilities of the firm and the college in this field. A memorandum setting forth the requirements of the Council, the responsibility of the firm and the responsibility of the college has been issued for the guidance of firms and colleges (Memorandum on the Industrial Training of Students following Courses recognized as leading to the Diploma in Technology. Pp. 11). At the conclusion of a course the firm will be responsible for assessing the extent to which the student has benefited from his industrial training and for certifying to the college that he has completed his training satisfactorily. The college is responsible for certifying to the Council, in the light of this certification, that the student has completed satisfactorily a course of industrial training in accordance with the Council's requirements, as well as for making appropriate arrangements for collaborating with firms and ensuring that where the training is received at more than one firm the complete scheme of training followed complies with the statement of the broad nature and sequence of training required for the particular course. The Council has also issued a List of ninety-five courses at twenty-three colleges which are now recognized as leading to the Diploma in Technology (List No. 11. Diploma in Technology. Pp. 5).

\section{Polar Research in the U.S.S.R.}

THE first Arctic drift expedition, led by I. D. Papanin, took place in 1937-38. Six expeditions of the same type followed, and since 1954 drifting Arctic stations are a constant feature of the regular survey. Recent progress of this work is reviewed by P. A. Gordienko (Priroda, 6, 35; 1959), while recent progress in the oceanography studies in the Aretic is described by A. F. Treshnikov (Priroda, 2, 25; $1960)$, especially all the work done on the distribution of currents, temperature, chemistry and biology of the Aretic Ocean as influenced by the submarine Lomonosov ridge. The work of the Antarctic expedition of the Academy of Sciences is constantly under review. K. A. Brodsky, K. K. Markov and V. I. Shilnikov (Priroda, 7, 19; 1959) give a summary account of the geographical zonality at high latitudes of the southern hemisphere. It is provided with a map in colour and several sections illustrating the distribution of temperature and salinity in the different parts of the ocean. The glacial cover of the Antarctic, os determined by the seismic survey, is discussed by $\mathbf{Y}$. M. Model and A. V. Nudelman (Priroda, 11, 93; 1959), who have assembled together the results of the various national expeditions. They give an outline structural map of the Antarctic continent with indications of the probable mountain ranges and rift troughs.

\section{International Bird Preservation}

IN its annual report for 1959 the British Section of the International Council for Bird Preservation announces the additions of the U.S.S.R., Portugal and Malaya to the national sections of the Council, bringing the total number of subscribing countries to forty-eight. Another important event has been the setting up of a special sub-committee of the British Trust for Ornishology to investigate the injurious effects of pesticides on wild life. Reference is made to the mass destruction of small birds in Italy to be served up as savoury dishes to tourists. Individual tourists, it is elaimed, can do much to eliminate this practice by expressing their displeasure and disgust when they see small birds served in restaurants. The Indonesian authorities are trying to control the clandestine traffic of birds of paradise plumes between New Guinea and Singapore. These beautiful birds face the threat of destruction while their plumes are in demand for purposes of personal adornment. The report also points out that, while Lord Ilchester was one of the first to raise the question of oil pollution of the sea in the House of Lords nearly forty years ago, the evil still persists. When the International Convention for the Prevention of the Pollution of the Sea by Oil came into force on July 26, 1958, eleven maritime countries had ratified; on March 2, 1959, Finland ratified, thus bringing the total up to twelve. It has since been announced that the United States has also accepted the International Convention, though with certain technical reservations. The report of the British Section may be obtained from the International Council for Bird Preservation, c/o British Museum (Natural History), Cromwell Road, London, S.W.7, price $3 s$.

\section{South Australia Museum}

The annual report for 1958-59 of the South Australian Museum in commenting on the field work accomplished describes the search for Tertiary mammalian records in the Lake Eyre Basin (Pp. 15. Adelaide: Government Printer, 1960). This was a joint expedition with the University of California and enabled a clearer picture to be obtained of the stratigraphy of the region than had been possible before. Several other expeditions were arranged, and such activities should be an incentive to museums in Great Britain to conduct similar work in spite of the financial position. The Cave Exploration Group has undertaken further work at the Specimen Cave, Naracoorte. An underwater research group has also been formed and is being fostered by the museum. Its activities - in which many members of the staff take part-has added many specimens to the marine collections.

\section{Classification of Pharmaceutical Preparations}

BECAUSE of the toxic or dangerous nature of many pharmaceutical preparations, special regulations are necessary to prevent risks of poisoning and other risks to which they may give rise. Trade in pharmaceutical preparations must be controlled, and for this purpose a classification of such preparations must be established. Twenty years ago it was relatively easy to establish such a classification, but since then hundreds of now preparations have been put on the market, and earlier systems of classification do not fully satisfy present requirements. The principles which inspired or still inspire such classifications vary from country to country. These regulations contain two common elements: certain pharmaceutical preparations may be supplied only against a medical prescription, and some may be sold only by pharmacists. Despite these common factors, the regulations of different countries vary considerably so that any possible attempt at obtaining uniformity is beset with difficulties. A survey of comparative health legislation based on health laws and regulations published in the International Digest of Health Legis- 